九州大学学術情報リポジトリ

Kyushu University Institutional Repository

\title{
Cloning and Characterization of a Laccase Gene from Biotechnologically Important Basidiomycete Cerrena Unicolor
}

Janusz, Grzegorz

Department of Biochemistry, Maria Curie-Skłodowska University

Mazur, Andrzej

Checinsks, Aleksandra

Department of Biochemistry, Maria Curie-Skłodowska University : Environmental Biotechnology

Institute, Environmental Science Program, University of Idaho

Malek, Wanda

Department of Genetics and Microbiology, M. Curie-Skłodowska University

他

https://doi.org/10.5109/22046

出版情報：九州大学大学院農学研究院紀要. 57 (1)，pp.41-49，2012-02. Faculty of Agriculture， Kyushu University

バージョン :

権利関係 : 


\title{
Cloning and Characterization of a Laccase Gene from Biotechnologically Important Basidiomycete Cerrena Unicolor
}

\author{
Grzegorz JANUSZ ${ }^{1}$, Andrzej MAZUR ${ }^{2}$, Aleksandra CHECINSKS ${ }^{1, a}$, Wanda MALEK ${ }^{2}$, \\ Jerzy ROGALSKI ${ }^{1}$ and Shoji OHGA*
}

\author{
Laboratory of Forest Resources Management, Division of Forest Environmental Sciences, \\ Department of Agro-environmental Sciences, Kyushu University, \\ Sasaguri, Fukuoka 811-2415, Japan \\ (Received October 31, 2011 and accepted November 9, 2011)
}

\begin{abstract}
The laccase gene lac1 and its corresponding full-length cDNA from white-rot fungi Cerrena unicolor with high yield of laccase production and potential use in electrochemical studies, was cloned and characterized. The $1533 \mathrm{bp}$ full-length cDNA of lac1 encoded a mature laccase protein containing 510 amino acids was preceded by a signal peptide of 20 amino acids. The deduced protein sequence of lac1 shared similarity with other known fungal laccases and contained four copper-binding conservative domains of typical laccase protein An inferred TATA box and several putative CAAT, MRE, XRE consensus sequences were identified in the lac1 promoter region. A number of putative consensus sequences such as those binding AP1, AP2, creA and NIT2 transcription factors, involved in nitrogen and carbon regulation in different fungi, were also present in the promoter region of Cerrena unicolor laccase gene.
\end{abstract}

Key words: Cerrena unicolor, laccase, laccase gene promoter region

\section{INTRODUCTION}

Filamentous fungi play an important role in biotechnology due to the production of low-molecular-weight compounds and enzymes (Mander et al., 2006). The importance of cellulolytic, hemicellulolytic and lignolytic enzyme's complexes, that are dominant in the saprophytic mode of life of filamentous fungi, has been described in a considerable amount of literature. Along with other hydrolases, these enzymes find important applications in biotechnology and industry (Ng, 2004).

Over the last decades, laccases, the major enzymes in ligninolytic complex, have received much attention especially due to their ability to oxidize both phenolic and nonphenolic lignin related compounds as well as highly recalcitrant environmental pollutants Such applications include: degradation or/and detoxification of industrial effluents, mostly from the pulp and paper, textile and petrochemical industries, medical diagnostic tools and as a bioremediation agents to clean up herbicides, pesticides and certain explosives in soil (Rodriguez-Couto and Toca-Herrera, 2006). However, expressing high levels of stable and functional proteins remains the bottleneck of many scientific and biotechnological endeavors, including the determination of structures in a high-throughput fashion, design, engineering and directed evolution of tailor-made proteins (Roodvelt et al., 2005).

\footnotetext{
${ }^{1}$ Department of Biochemistry, Maria Curie-Skłodowska University, Akademicka 19 St., 20-033 Lublin, Poland

${ }^{2}$ Department of Genetics and Microbiology, M. CurieSkłodowska University, Akademicka 19 St., 20-033 Lublin, Poland

a Present address:Environmental Biotechnology Institute, Environmental Science Program, University of Idaho, Moscow, Idaho, 83844

* Corresponding author: (E-mail: ohga@forest.kyushu-u.ac.jp)
}

Cerrena unicolor was found by Leonowicz et al. (1997) as a new potential source of a unique laccase that produces the enzyme under non-induced conditions at the same rate as other superior laccase producers after the induction (Rogalski et al., 1999). Latter experiments followed optimization of medium composition concerning carbon and nitrogen sources content as well as copper ion concentration and fermentor culture parameters leading to higher production of laccase (Janusz et al., 2007). Several attempts of laccase purification from Cerrena unicolor resulted in different number of isoenzymes, ranging from two to four and were followed by complete enzyme characteristics (Kim et al., 2002; Michniewicz et al., 2006; Rogalski and Janusz, 2010). Laccase from Cerrena unicolor was found to be useful in degradation of lignosulfonate (Cho et al., 2004), bioscouring of linen fabrics (Sójka-Ledakowicz et al., 2007), electrochemistry (Klis et al., 2007; Shleev et al., 2007, Nazaruk et al., 2010), detection of mono- and diphenols (Jarosz-Willkolazka et al., 2005), demethoxylation of milled wood lignin (Leonowicz et al., 2000) and decolorization of aqueous solution of dyes (Michniewicz et al., 2003). Despite many potential applications of laccases, genes encoding such enzymes in Cerena unicolor have been poorly characterized There are only two GenBank records concerning patented sequences and one more sequence from the unpublished data. Apart from those, there were no attempts to analyze Cerrena unicolor laccase gene nor the promoter region In this study, we fully characterized Cerrena unicolor laccase gene and described a promoter region. We have also examined previous works on medium optimization enhancing laccase production and enzyme purification. 


\section{MATERIAL ANDMETHODS}

\section{DNA manipulation techniques}

Standard techniques for plasmid isolation, restriction enzyme digestion, agarose gel electrophoresis and DNA cloning were employed (Sambrook et al., 1989). Automatic Sequencing was performed using BigDye ${ }^{\mathrm{TM}}$ Terminator Cycle Sequencing Kit and ABI PRISM 310 sequencer or ABI PRISM 3730 XL (Applied Biosystems, Carlsband, CA, USA).

\section{Culture conditions}

Cerrena unicolor strain C-139 was obtained from the culture collection of the Regensberg University. The fungus was maintained on $2 \%(\mathrm{w} / \mathrm{v})$ malt agar slants. As an inoculum, pieces of agar were grown in Lindenberg and Holm medium (Lindeberg and Holm, 1952) in nonagitated conical flasks for 7 days at $28^{\circ} \mathrm{C}$.

\section{Genomic DNA isolation}

A culture of $C$. unicolor was grown stationary in Lindeberg and Holm medium (Lindeberg and Holm, $1952)$ at room temperature $\left(25^{\circ} \mathrm{C}\right)$ for 7 days. Mycelia were harvested through Miracloth (Merck, Whitehouse Station, NJ, USA), washed twice with TE buffer, and frozen in liquid nitrogen. DNA was isolated according to Borges et al. (1990). The purity and quantity of the DNA samples were evaluated using ND-1000 spectrophotometer (Thermo Scientific, West Palm Beach, FL, USA).

\section{Preparation of total mRNA}

Cerrena unicolor was grown in 100-ml conical flasks containing $40 \mathrm{ml}$ Lindeberg and Holm medium suitable for laccase production (Janusz et al., 2007) at $25^{\circ} \mathrm{C}$ with shaking at $180 \mathrm{rpm}$. Synthesis of laccase mRNA was induced by adding $10 \mathrm{mM}$ of $\mathrm{CuSO}_{4}$ during the $3^{\text {rd }}$ and $6^{\text {th }}$ day as in Janusz et al., 2007. Isolation of total RNA was performed on the $7^{\text {th }}$ day using GenElute Direct mRNA Miniprep Kit (Sigma-Aldrich, Tokyo, Japan). The purity and quantity of the RNA samples were evaluated using ND-1000 spectrophotometer (Thermo Scientific, West Palm Beach, FL, USA).

\section{PCR amplification of ITS region}

PCRs were performed using Sigma RedTaq in a Tpersonal thermal cycler (Biometra, Goettingen, Germany). To confirm the identity of the fungus, the ITS region in the nuclear ribosomal repeat unit was determined by direct sequencing of the PCR products amplified with ITS1-ITS2 and ITS3-ITS4 primers as described previously (White et al., 1990; Gardes and Bruns, 1993).

\section{cDNA synthesis and amplification}

Total mRNA $(2.0 \mu \mathrm{g})$ and $80 \mathrm{pmol}$ of the oligo(dT) primer were used to synthesize the first strain of complementary DNA (cDNA) with Transcriptor High Fidelity cDNA synthesis Kit (Roche, Sydney, Australia) To amplify laccase's cDNA, primers identical to the ones used for amplification of respective DNA fragments, were used (Table 1). All PCR amplifications were carried out using Sigma RedTaq in a Tpersonal thermocycler (Biometra, Goettingen, Germany). Specific PCR products were purified using the Clean-up kit (A\&A Biotechnology, Gdynia, Poland) and inserted into pTZ57R/T vector from InsTAclone kit (Fermentas, Glen Burnie, MA, USA). Clones with target fragments were analyzed by sequencing.

\section{Amplification and cloning of lac1 gene}

To amplify the laccase gene, pairs of primers were designed on the basis of the conservative sequences of other fungal laccases (Table 1). All PCR amplifications were carried out using Sigma RedTaq in a Tpersonal thermal cycler (Biometra, Goettingen, Germany). Specific PCR products were purified using the Clean-up kit (A\&A Biotechnology, Gdynia, Poland) and inserted into pTZ57R/T vector from InsTAclone kit (Fermentas, Glen Burnie, MA, USA). Clones with target fragments were analyzed by sequencing.

Table 1. Gene-specific primer sequences and their annealing temperatures

\begin{tabular}{lll}
\hline Primer & \multicolumn{1}{c}{ Sequence 5' -3 ' } & \multicolumn{1}{c}{$\mathrm{Tm}\left[{ }^{\circ} \mathrm{C}\right]$} \\
\hline LCR & GTGGGSAAGGTRAACGTGCC & $55.9-57.9$ \\
LCF & GAYGGTTCCTGTACRACTTCCAKGT & $56.0-61.0$ \\
Fwzew & CCCATCKTSTCTTGTATCCTGTGAAG & $58.0-59.5$ \\
Rwzew & TAATAGAGTAKACACAAKAWTGTAGACYTCAAAG & $56.0-59.6$ \\
cDNAFw & CCCCCCTTCGGTTCCTGTT & 55.4 \\
cDNARw & TTGTGAGGATCTGAAGGGTCGTAG & 57.4 \\
SDFP 4 & CAGTTCAAGCTTGTCCAGGAATTCNNNNNNNCGCGT & $63.3-71.3$ \\
ND & CAGTTCAAGCTTGTCCAGGAATTC & 55.7 \\
BSP & CGTCGCCCCTGATATAAAATGGTCGTG & 61.3 \\
NSP & ATCGGGGGCAATGGTATCGT & 53.8 \\
\hline
\end{tabular}

BSP, biotinylated specific primer; SDFP, semi-degenerate flanking primer; ND, nondegenerate; NSP, nested-specific primer; N - A, T, G or C 


\section{Amplification and cloning of laccase promoter region using AFR-PCR}

To amplify the laccase promoter region amplified flanking region-PCR (AFR-PCR) technique described by Soden and Dobson (2003) was used Biotinylated specific primer was designed on the basis of laccase gene sequence (Table 1). All PCR amplifications and Dynabead-streptavidin purification were carried out according to Soden and Dobson (2003). Specific PCR products were purified using the Clean-up kit (A\&A Biotechnology, Gdynia, Poland) and inserted into pTZ57R/T vector from InsTAclone kit (Fermentas, Glen Burnie, MA, USA). Clones with targeted fragments were analyzed by sequencing.

\section{Nucleotide sequence accession numbers}

The following GenBank accession numbers were assigned to the nucleotide or aminoacid sequences determined in this study (Table 2).

\section{Bioinformatic tools}

Data from sequencing was analyzed with Lasergene v.8.0 analysis software (DNASTAR, Inc). Data base searches were performed with the BLAST and FASTA programs at the National Centre for Biotechnology Information (Bethesda, MD, USA) and European Bioinformatic Institute (Hinxton, UK). The DNA and proteins sequence's multiple alignments were performed with Clustal-W algorithm (Thompson et al., 1994) Phylogenetic trees visualization was performed using TreeView applet (Page, 1996). Glycosylation sites were detected with NetNGlyc v.1.0 (http://www.cbs.dtu.dk/ services/NetNGlyc/).

\section{$\mathbf{N}$-terminal sequencing}

The N-terminal amino acid sequence of the purified laccase was determined in Biocentrum in Cracow (Poland) by step-wise Edman degradation with Procise 491 protein Micro Sequencer (Applied Biosystems, Carlsband, CA, USA) equipped with a high performance liquid chromatography system for the on-line phenylthiohydantoin-amino acid identification. Proteins separated by SDS-PAGE were electroblotted into a polyvi- nylidene difluoride membrane as in Walker (2002) and the excised bands were directly analyzed.

\section{Mass spectrometry (MS)}

Protein samples obtained during enzyme purification were separated on SDS-PAGE gels in 10\% Tris-HCl as in Walker (2002) and visualised by Coomassie Brilliant Blue R-250 staining according to Walker (2002). After the electrophoretic separation of samples, equal pieces of $2 \times 7 \mathrm{~mm}$ were cut out from experiment gel lanes. The spectrometric analysis of the polypeptides was carried out in the Environmental Laboratory of Mass Spectrometry, Institute of Biochemistry and Biophysics of the Polish Academy of Sciences in Warsaw (Poland). The samples were analyzed by HPLC coupled with tandem mass spectrometry (liquid chromatography/two stage mass spectrometry - LC-MS/MS), according to Kordan et al. (2007). The output list of precursor and product ions was compared with the protein database of the National Center for Biotechnology (NCBI, USA), using the MASCOT local server.

\section{RESULTS}

\section{PCR amplification of ITS region}

Two products of $260 \mathrm{bp}$ and $370 \mathrm{bp}$ were obtained from PCR with ITS1-ITS2 and ITS3-ITS4 primers, respectively, and followed by direct sequencing. The complete sequences of these products (648 bp) indicated over 99 $\%$ identity to the Cerrena unicolor ITS seqences.

\section{Nucleotide sequence of lac1 cDNA}

Full length of the lac1 cDNA from Cerrena unicolor was amplified, cloned and the sequence was determined. The analysis of obtained results revealed one open reading frame of $1533 \mathrm{bp}$ with G-C content of $52.51 \%$ and 510 amino acids including a signal sequence within the first 20 amino acids (Fig. 1). The predicted molecular weight (mol. Wt) of investigated laccase was calculated for $54837 \mathrm{Da}$ and had the isoelectric point of 4.69 .

Three possible N-glycosylation sites (Asn-X-Thr/Ser) were estimated by the NetNGlyc v.1.0 software (Fig. 1). A potential N-glycosylation site was found at positions

Table 2. GenBank accession numbers of the nucleotide or aminoacid sequences determined in this study

\begin{tabular}{cl}
\hline $\begin{array}{c}\text { GenBank accession } \\
\text { number }\end{array}$ & Definition \\
\hline DQ056858 & $\begin{array}{l}\text { Cerrena unicolor voucher FCL } 139 \text { 18S ribosomal RNA gene, partial } \\
\text { sequence; internal transcribed spacer 1, 5.8S ribosomal RNA gene, and } \\
\text { internal transcribed spacer 2, complete sequence; and 28S ribosomal RNA } \\
\text { gene, partial sequence }\end{array}$ \\
FJ594064 & Lerrena unicolor strain FCL139 Lac1 (lac1) mRNA, complete cds \\
ACL93462 & Cerrena unicolor lac1b N-terminal sequence \\
P85308 & Cerrena unicolor strain FCL139 lac1 gene and promoter region \\
\hline
\end{tabular}




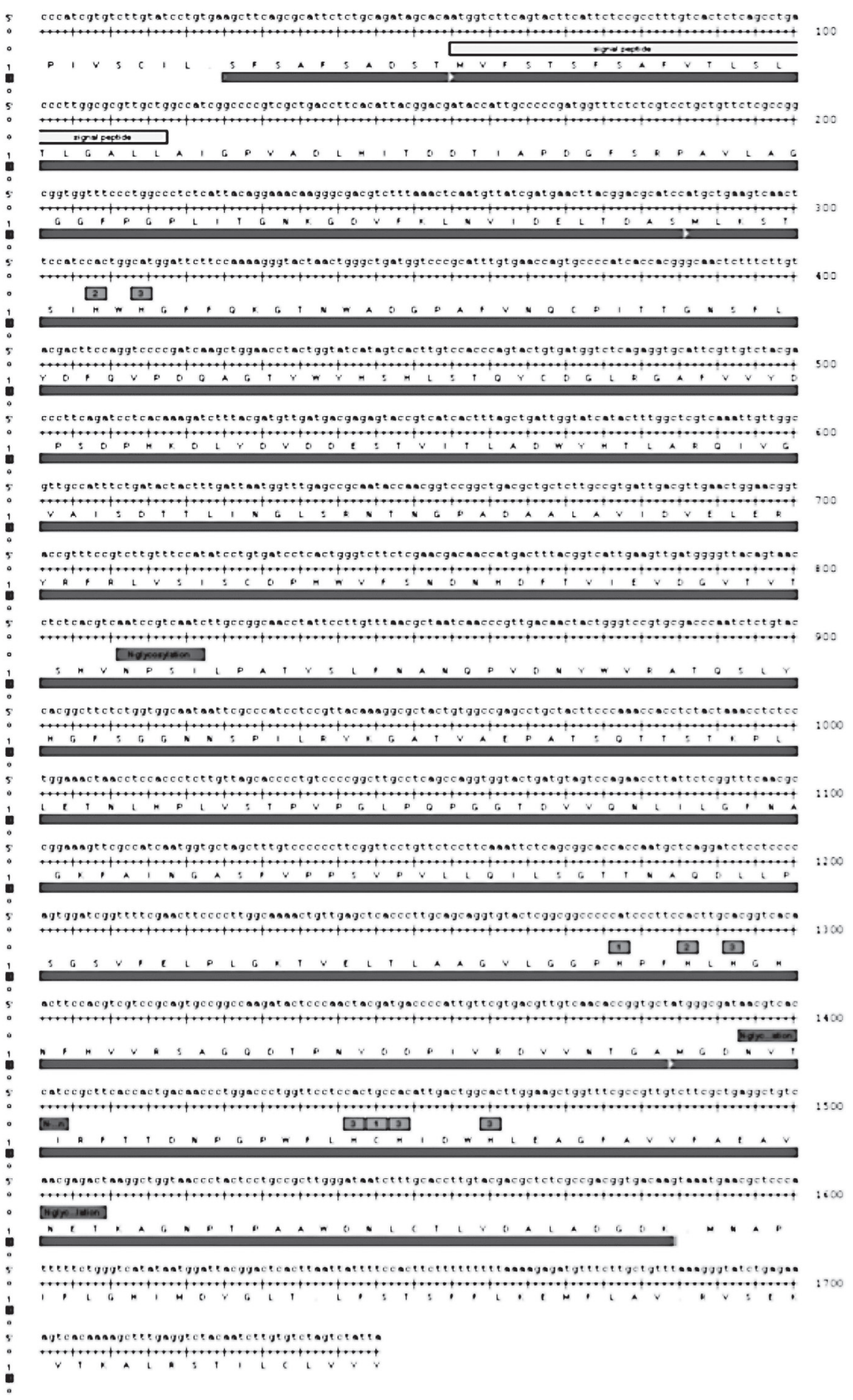

Fig. 1. Nucleotide sequence of a complete lac1 ORF with the estimated protein sequence shown with single-letter symbols below their capitalized codon. The translated amino acids are shown with single-letter symbols below their capitalized codon. The signal peptide sequence has been boxed. Residues implicated in copper coordination are enclosed in single boxes and numbered depending on the type of copper that they coordinate. Hypothetical $N$-glycosylation sites are underlined

Asn-253, Asn-447 and Asn-483.

The $\mathrm{Cu}^{2+}$ ligands binding sites were found in all blue copper oxidases, consisting of conservative 10 histidines and 1 cysteine, were detected in lac1 laccase in positions: H85, H87, H130, H132, H408, H411, H413, H463, $\mathrm{H} 465$, H469, and C464.
The dendrogram obtained from the alignments of 18 laccase amino acid sequences of Polyporales (Fig. 2), order to which Cerrena unicolor is assigned to, indicated that genes of these fungi are monophyletic including laccases from Spongipellis sp. and Panus rudis, which seem to be the closest to C. unicolor. However, 


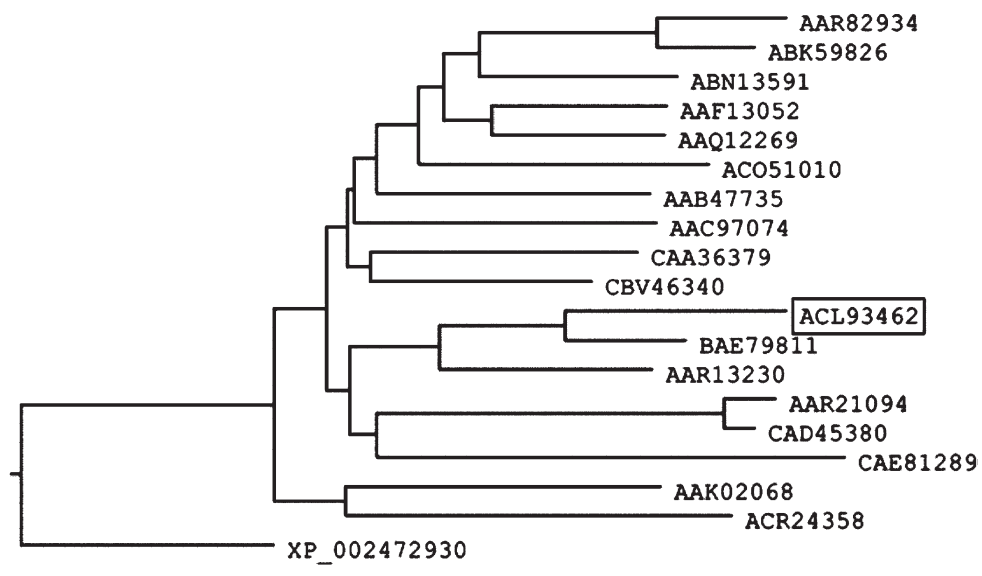

Fig. 2. Unrooted UPGMA based phylogenetic trees constructed with: 19 protein sequences The dendrogram of several laccases from fungi of Polyporales generated by neighbour-joined method using the MegAlign (DNASTAR) program. AAR82934-Ganoderma lucidum, ABK59826-Ganoderma fornicatum, ABN13591-Polyporus brumalis, AAF13052Pycnoporus cinnabarinus, AAQ12269-Trametes sp. I-62, ACO51010-Pycnoporus sanguineus, AAB47735-Trametes villosa, AAC97074-Gelatoporia subvermispora, CAA36379-Phlebia radiata, CBV46340-Meripilus giganteus, BAE79811-Spongipellis sp. FERM P-18171, AAR13230-Panus rudis, AAR21094-Pleurotus ostreatus, CAD45380-Lentinus sajor-caju, CAE81289-Rigidoporus microporus, AAK02068Coriolopsis galica, ACR24358-Polyporus grammocephalus, XP_002472930-Postia placenta.

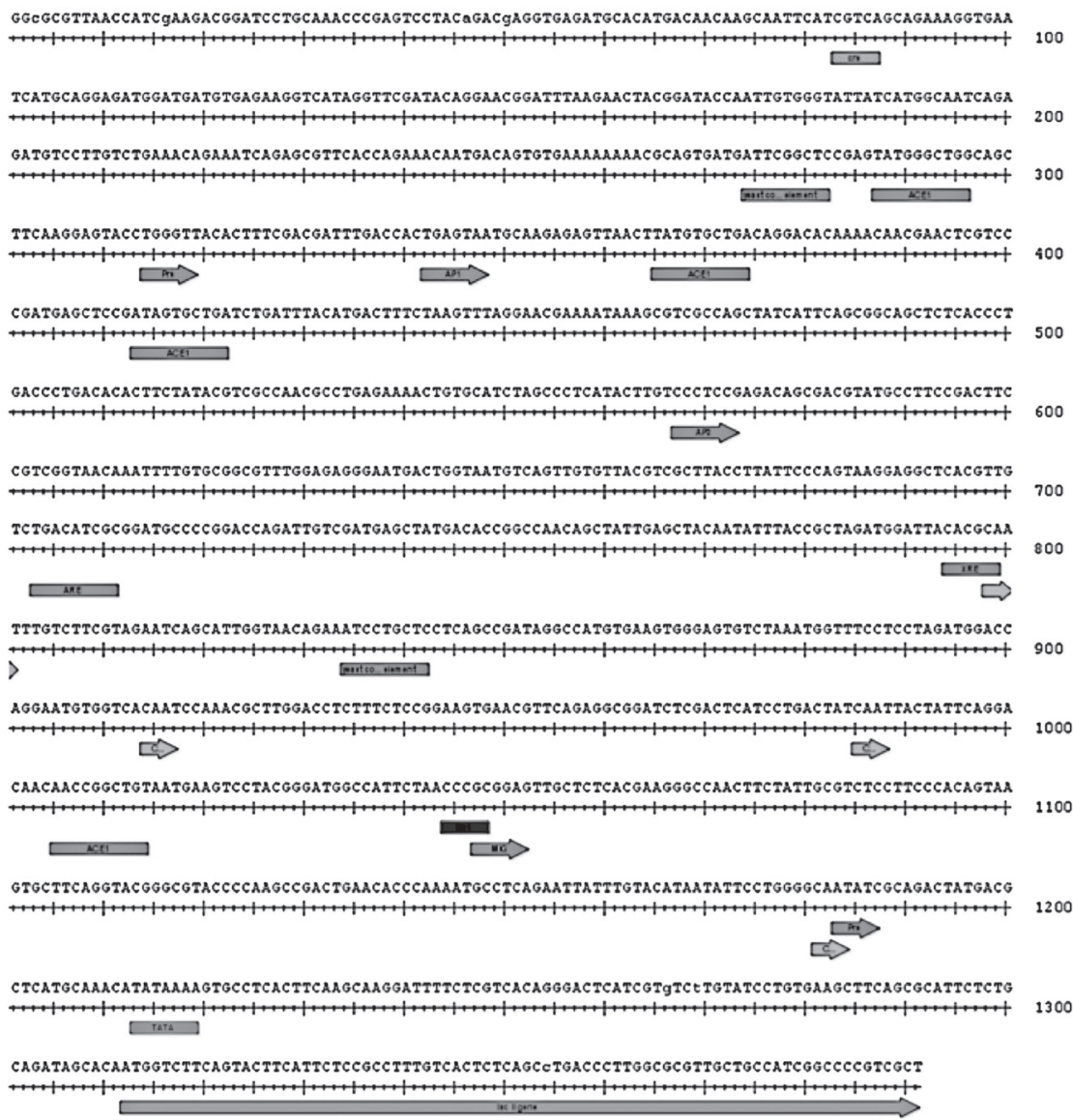

TITGTCTTCGTAGAATCAGCATTGGTAACAGAAATCCTGCTCCTCAGCCGATAGGCCATGTGAAGTGGGAGTGTCTAAATGGTTTCCTCCTAGATGGACC

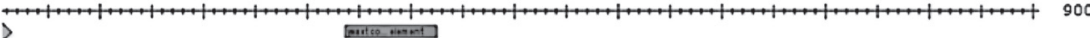

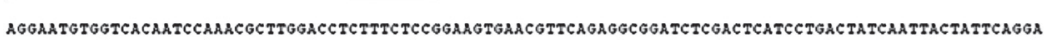
(1000) CAACAACCGGCTGTAATGAAGTCCTACGGGATGGCCATTCTAACCCGCGGAGTTGCTCTCACGAAGGGCCAACTTCTATTGCGTCTCCTTCCCACAGTAA

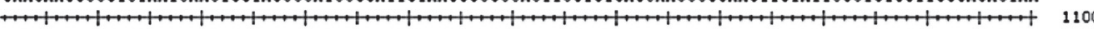

GTGCTTCAGGTACGGGCGTACCCCAAGCCGACTGAACACCCAAARTGCCTCAGAATTATTTGTACATAATATTCCTGGGGCAATATCGCAGACTATGACG

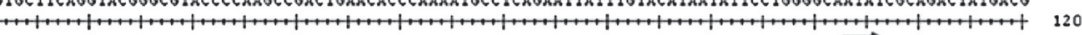
도

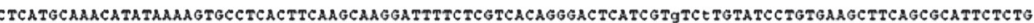

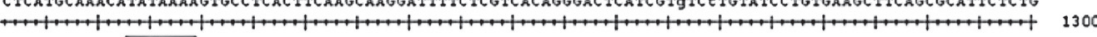

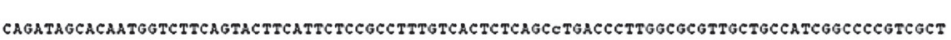

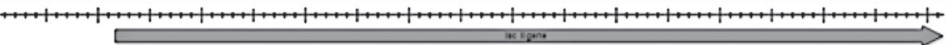

Fig. 3. The nucleotide sequence of the promoter regions of the Cerrena unicolor lac1 gene. Various response elements were identified as follows: putative (PRE, cAMP response element (creA), nitrogen response elements AP2, mammalian enhancer element (Sp1), carbon response element (Mig) and the putative antioxidant response element AP1. At the site around $900 \mathrm{bp}$ upstream of the ATG, an element closely matching the ACE1 transcription factor consensus sequence was found. 
all three sequences belong to the cluster that included laccases from Pleurotus ostreatus, Lentinus (Pleurotus) sajor-caju and Rigidoporus microporus.

\section{Nucleotide sequence of lac1 genomic DNA}

To precisely determine location of introns in the lac1, genomic DNA from Cerrena unicolor was amplified by PCR using primers designed based on the nucleotide sequence of the lac1 cDNA as described in Materials and methods section. A fragment of $2341 \mathrm{bp}$ was amplified by PCR and sequenced. The position of putative introns within the laccase gene was determined by comparison of the genomic DNA and cDNA sequences. Ten introns that ranged in size from 52 to $70 \mathrm{bp}$ were found to be present inside the lac1 gene and fall into the GT-AG rule (Padgett et al., 1984).

\section{$\mathbf{N}$-terminal peptide sequence analysis}

Cerrena unicolor laccase protein was purified according to the previously described procedure (Rogalski and Janusz, 2010) and sequenced by Edman method. The first 9 amino acid residues at the $\mathrm{N}$-terminus were AIGPVADLH (Accession number P85308.1). This sequence was identical to residues from 21 to 30 of the precursor protein encoded by lac1 (Fig. 1) and implied that the protein undergoes posttranslational proteolytic cleavage at position 20 .
Analysis of putative promoters for consensus elements

The 1310 bp 5'-flanking sequence upstream of the start codon ATG in lac1 gene was obtained by AFR-PCR and then analyzed for the presence of putative cis-acting elements involved in transcriptional regulation. The putative promoter region of lac1 gene extending 1310 bp upstream of the start codon was shown in Fig. 3. The TATA box was located at positions $-108 \mathrm{bp}$ upstream from the start codon ATG and four CAAT boxes were located at $-128,-324,-395$, and -511 position, respectively. Additionally, some other putative response elements were also found in the promoter region (Fig. 3). A putative heat shock element (NGAANNTTCN) (Bonner et al., 1994) at -356, one putative metal-responsive element (MRE) adhering to the consensus sequence TGCRCNC (Thiele, 1992) was detected and centered at bp positions -251, cAMP response element was located at position -1225 (Soden and Dobson, 2003). One of putative xenobiotic-responsive elements (XREs) matching the consensus sequence CACGCW (Rushmore et al., 1990) was located at position -513, four ACE elements adhering to the consensus sequence HWHNNGCTGD or NTNNHGCTGN at positions -298, -890, -938, -1016, respectively (Fan et al., 2011). Two TGGGTT motifs were present at positions $-993 \mathrm{bp}$, the motif ATATC occuring at position -125 , which also occurs regularly in the upstream regions of laccase genes The mammalian

Table 3. Summary of matched peptide queries for laccase in lac1b band

\begin{tabular}{lll}
\hline Primer & \multicolumn{1}{c}{ Sequence 5' ${ }^{\prime} 3^{\prime}$} & Tm $\left[{ }^{\circ} \mathrm{C}\right]$ \\
\hline LCR & GTGGGSAAGGTRAACGTGCC & $55.9-57.9$ \\
LCF & GAYGGTTCCTGTACRACTTCCAKGT & $56.0-61.0$ \\
Fwzew & CCCATCKTSTCTTGTATCCTGTGAAG & $58.0-59.5$ \\
Rwzew & TAATAGAGTAKACACAAKAWTGTAGACYTCAAAG & $56.0-59.6$ \\
cDNAFw & CCCCCCTTCGGTTCCTGTT & 55.4 \\
cDNARw & TTGTGAGGATCTGAAGGGTCGTAG & 57.4 \\
SDFP 4 & CAGTTCAAGCTTGTCCAGGAATTCNNNNNNNCGCGT & $63.3-71.3$ \\
ND & CAGTTCAAGCTTGTCCAGGAATTC & 55.7 \\
BSP & CGTCGCCCCTGATATAAAATGGTCGTG & 61.3 \\
NSP & ATCGGGGGCAATGGTATCGT & 53.8 \\
\hline
\end{tabular}

1 MVFSTSESAF VTLSLTLGAL LAIGPVADLH ITDDTIAPDG FSRPAVLAGG

51 GFPGPLITGN KGDVFKLNVI DELTDASMLK STSIHWHGFF QKGTNWADGP

101 AFVNQCPITT GNSFLYDFQV PDQAGTYWYH SHLSTQYCDG LRGAFVVYDP

151 SDPHKDLYDV DDESTVITLA DWYHTLARQI VGVAISDTTL INGLSRNTNG

201 PADAALAVID VELERYRERL VSISCDPHWV FSNDNHDETV IEVDGVTVTS

251 HVNPSILPAT YSLFNANQPV DNYWVRATQS LYHGESGGNN SPILRYKGAT

301 VAEPATSQTT STKPLLETNL HPLVSTPVPG LPQPGGTDVV QNLILGFNAG

351 KFAINGASFV PPSVPVLLQI LSGTTNAQDL LPSGSVFELP LGKTVELTLA

401 AGVLGGPHPF HLHGHNEHVV RSAGQDTPNY DDPIVRDVVN TGAMGDNVTI

451 RETTDNPGPW ELHCHIDWHL EAGEAVVFAE AVNETKAGNP TPAAWDNLCT 501 LYDALADGDK

Fig. 4. Complete sequence of laccase (ACL93462) with matched peptides in bold (sequence coverage: $18 \%)$. 
Sp-1 transcription factor recognition site CCCGC was located at position -264 in the lac1 gene promoter (Soden and Dobson, 2003) and antioxidant response elements (ARE) with the consensus sequence TGACNNNGC at position -601 in lac1 promoter together with putative AP1 at -964 and AP2 at -739 (Rushmore et al., 1991; Soden and Dobson, 2003).

\section{Analysis of Proteins by SDS-PAGE and LC-MS/MS}

To identify laccase isoforms of $C$. unicolor determinated by SDS-PAGE, gel slices were excised, digested with trypsin and analyzed by LC-MS spectrometry. The MS/MS raw data were used to search against NCBI protein database. A protein was identified when MASCOT probability-based score $(\mathrm{p}<0.05)$ was greater than 52 Laccase from $C$. unicolor (Accession no. ACL93462) was detected in each gel slice, with the highest score for the band lac1b (Rogalski and Janusz, 2010), that corresponds to the isoform sequence available in the protein database. The identified protein had (Table 3) MASCOT score of 756 and sequence coverage of $18 \%$ (Fig. 4). The molecular mass of 55,089 Da of the identified laccase was very close to the molecular mass determined by SDS-PAGE (54.49_3.38) (Rogalski and Janusz, 2010).

\section{DISCUSSION}

The purification and characterization of four laccase isoforms from Cerrena unicolor C-139 was already published by Rogalski and Janusz (2010). However, the laccase gene sequences of tested organism had not been reported yet In our work, we demonstrate cloning of the lac1 cDNA and promoter sequence that allows for a more complete and advanced examination of the laccase gene in this biotechnologically important fungus.

Taking into consideration in silico laccase characteristics as well as protein $N$-terminal sequence and LC-MS analysis we found that lac1 gene seems to be coding for lac1b-type laccase described earlier by Rogalski and Janusz (2010). Deducing from the cDNA sequences, the calculated molecular weight of the mature protein of 510 amino acids - lac1b was $54.8 \mathrm{kDa}$. Despite considering glycosylation content (1.84\%), the calculated and measured molecular weight slightly differed from each other in the range of 4.9 to $7.3 \%$ ( $\pm 1.84 \%)$ (Rogalski and Janusz 2010).

The active site of laccases contained four copper ions: a mononuclear "blue" copper ion (T1 site) and a three nuclear copper clusters (T2/T3 site) consisting of one T2 copper ion and two T3 copper ions (Morozowa et al., 2007). It was earlier proved by an atomic absorption spectroscopy (AAS) method that the purified laccase contained four copper ions (Rogalski and Janusz, 2010). Here, we demonstrated using in sillico analysis the presence in the laccase cDNA sequence, the exact motif of 10 histidines and 1 cysteine, which is conserved in fungal laccases.

The amino acid residue at 10 amino acids downstream to the conserved cysteine had an important effect on the redox potential of the type 1 copper at the active site. Based on the amino acids differences of this residue, laccases were proposed to be classified into three types: class 1 (Met), 2 (Leu), and 3 (Phe). It was suggested that the presence of Phe at this position is necessary for a high redox potential in fungal laccases. Moreover, the Leu-Glu-Ala triad at positions +6 to +8 downstream to the conserved Cys was also considered to be important for a high redox potential (Canters and Gilardi 1993; Xu et al., 1996; Eggert et al., 1998) To our knowledge Cerrena unicolor laccase belongs to class 3 and it seems to be an enzyme of a high potential (Shleev et al., 2007).

Ten introns ranging in size from 52 to $70 \mathrm{bp}$ in the laccase gene with splicing junctions and internal lariat formation sites adhered to the GT-AG rule (Padgett et al., 1984). Lac1 gene seemed to be comparable with those of other fungal laccases, which were characterized by presence of various numbers of introns from 5 in $A$. nidulans yA up to 19 introns in $P$. ostreatus (strain Florida) pox 1 and pox2 with the average length $69 \mathrm{bp}$ in all fungal genes (Kinghorn and Turner, 1992; Okamoto et al., 2003).

Cerrena unicolor was capable of producing constitutive form of laccase, i.e. without any extracellular inductors, which are used to stimulate many other fungal species (Rogalski et al., 1999). Different patterns expression of laccase isozymes coded by gene families was regulated, depending on the growth conditions (Bollag and Leonowicz, 1984; Rogalski and Leonowicz, 1992) and physiological states of fungi (Mansur et al., 1998; Rogalski et al., 1993; Pezzella et al., 2009). Many works have proved that white rot fungi laccase is dependent not only on carbon and nitrogen concentrations but also on copper ion ones (Collins et al., 1997; Dittmer et al., 1997; Palmieri et al., 2000). Thus, it is probable that some specific transcriptional activation mechanisms are involved (Soden and Dobson, 2003).

Hence, in the effort to identify potential response elements involved in laccase gene regulation, the promoter region of $C$. unicolor lac1 gene was cloned. We proved that production of laccases in Cerrena unicolor depends on carbon, nitrogen and copper ion concentrations in the growth medium (Janusz et al., 2007). The analyses of lac1 promoter sequence seemed to confirm our earlier observations. The regulatory elements such as Mig, CRE, NIT1 and NIT2, known to be involved in carbon and nitrogen regulation of fungal gene expression and ACE1 transcription factor responsible for laccase synthesis due to copper induction (Soden and Dobson 2001, Soden and Dobson, 2003), were found in the promoter of lac1. Moreover the analysis of lac1 promoter sequence showed a metal response element which supports the results of cadmium induction described by Jarosz-Wilkolazka et al. (2006) MRE are typically found in metallothionein gene promoters in higher eukaryotes, suggesting that their expression could be induced by heavy metal ions such as $\mathrm{Cd}, \mathrm{Cu}$ and $\mathrm{Zn}$ (Imbert et al., 1990; Hamer, 1995, Soden and Dobson, 2003). Additionally, finding of HSE in lac1 promoter confirmed that laccase production may be up scaled in response to 
heat induction (Fink-Boots et al., 1997). Our current analysis proved the observation of Rogalski et al., (1999) indicated that the transcription of Cerrena unicolor laccase genes could be slightly activated by aromatic compounds (xylidine, ferulic acid and veratric acid). From our data, it is indicative that lac1 promoter contain sequence with perfect homology to XRE.

According to our knowledge, there is yet no known explanation on the high production of laccase in C. unicolor without any additional inducers (Janusz et al., 2007). Further studies concerning other Cerrena unicolor laccases genes, their promoters and the expression system would help understanding the constitutive nature of laccase production of this biotechnologically interesting fungus.

\section{ACKNOWLEDGEMENTS}

This work was partially financially supported by BS/ Bioch/UMCS grant and research program "Tailored Lipidic Mesophases as Novel Functional Nanomaterials in Bioenergetics and Biosensing" under the framework of Polish-Swiss Research Programme PSPB-079/2010

\section{REFERENCES}

Bollag, J.-M. and A. Leonowicz 1984 Comparative studies of extracellular fungal laccases. App. Environ. Microbiol., 48: 849-854

Bonner, J. J., C. Ballou and D. L. Fackenthal 1994 Interactions between DNA-bound trimers of the yeast heat shock factor. Mol. Cell. Biol., 14: 501-508

Borges, M. I., M. O. Azevedo, R. Bonatelli, M. S. S. Felipe and S. Astolfi-Filho 1990 A practical method for the preparation of total DNA from filamentous fungi. Fungal Gen. Newslett., 10: 11

Canters, G. W. and G. Gilardi 1993 Engineering type 1 copper sites in proteins. FEBS Lett., 325: 39-48

Cho, N.-S., W. Shin, S.-W. Jeongand and A. Leonowicz 2004 Degradation of lignosulfonate by fungal laccase with low molecular mediators. Bull. Korean Chem. Soc., 25(10): 15511554

Collins, P. J. and A. D. W. Dobson 1997 Regulation of laccase gene transcription in Trametes versicolor. App. Environ. Microbiol., 63: $3444-3450$

Dittmer, J. K., N. J. Patel and S. W. Dhawale 1997 Production of multiple laccase isoforms by Phanerochaete chrysosporium grown under nutrient suffciency. FEMS Microbiol. Lett., 149: 65-70

Eggert, C., P. R. LaFayette, U. Temp, K. E. L. Erikssonand and J. F. D. Dean 1998 Molecular analysis of a laccase gene from the white rot fungus Pycnoporus cinnabarinus. App. Environ. Microbiol., 64: 1766-1772

Fan, F., R. Zhuo, S. Sun, X. Wan, M. Jiang, X. Zhangand and Y. Yang 2011 Cloning and functional analysis of a new laccase gene from Trametes sp. 48424 which had the high yield of laccase and strong ability for decolorizing different dyes. Bioresour. Technol., 102: 3126-3137

Fink-Boots, M., M. Jaszek and A. Leonowicz 1997 Heat Shock Stimulation of Laccase in Abortiporus biennis and Cerrena unicolor. Second TAPPI Biological Sciences Symposium, San Francisco, October 19, 23: 395-396

Gardes, M. and T. D. Bruns 1993 ITS primers with enhanced specificity for basidiomycetes - application to the identification of mycorrhizae and rusts. Mol. Ecol., 2: 113-118

Hamer, D. H. 1995 Metallothionein. Annu. Rev. Biochem., 55: 913-951

Imbert, J., V. Culotta, P. Fürst, L. Gedamu and D. Hammer 1990
Regulation of metallothionein gene transcription by metals. In "Metal-ion Induced Regulation of Gene Expression", Vol. 8., ed by G. L. Eichorn and L. G. Marzilli, Elsevier Science Publishing Inc, New York, pp. 139-164

Janusz, G., J. Rogalski and J. Szczodrak 2007 Increased production of laccase by Cerrena unicolor in submerged liquid cultures. World J. Microb. Biotechnol., 23(10): 1459-1464

Jarosz-Wilkołazka, A., M. Grłz, B. Braha, S. Menge, D. Schlosserand and G.-J. Krauss 2006 Species-specific Cd-stress response in the white rot basidiomycetes Abortiporus biennis and Cerrena unicolor. BioMetals, 19: 39-49

Jarosz-Wilkołazka, A., T. Ruzgas and L. Gorton 2005 Amperometric detection of mono- and diphenols at Cerrena unicolor laccase-modified graphite electrode: correlation between sensitivity and substrate structure. Talanta, $\mathbf{6 6}(5)$ : 1219-1224

Kim, Y., N.-S. Cho, T.-J. Eom and W. Shin 2002 Purification and characterization of a laccase from Cerrena unicolor and its reactivity in lignin degradation. Bull. Korean Chem. Soc., 23 985-989

Kinghorn, J. R. and G. Turner 1992 Applied molecular genetics of filamentous fungi. Blackie Academic \& Professional, Glasgow

Klis, M., E. Maicka, A. Michota, J. Bukowska, S. Sek, J. Rogalski and R. Bilewicz 2007 Electroreduction of laccase covalently bound to organothiol monolayers on gold electrodes. Electrochimica Acta 52: 5591-5598

Leonowicz, A., J. Rogalski, E. Malarczyk, K. Grzywnowicz, G. Ginalska, J. Lobarzewski, S. Ohga, N. Pashenova, S.S. Lee and N.-S. Cho 2000 Demethoxylation of milled wood lignin and lignin related compounds by laccase from white-rot fungus Cerrena unicolor. J. Korean Wood Sci., 28(4): 29-40

Leonowicz, A., L. Gianfreda, J. Rogalski, M. Jaszek, J. Luterek, M. Wojtaś-Wasilewska, E. Malarczyk, A. Dawidowicz, M. FinkBoots, G. Ginalska and N.-S. Cho 1997 Extracellular laccase from the selected, best enzyme producing white-rot fungus Cerrena unicolor. Proc. Int. Sem. for Sci., Chungbuk Nat. Univ., Chengju, Korea, 15-34

Lindeberg, G. and G. Holm 1952 Occurrence of tyrosinase and laccase in fruit bodies and mycelia of some Hymenomycetes. Physiol. Plant, 5: 100-114

Mander, G. J., H. Wang, E. Bodie, J. Wagner, K. Vienken, C. Vinuesa, C. Foster, A. C. Leeder, G. Allen, V. Hamill, G. G. Janssen, N. Dunn-Coleman, M. Karos, H.G. Lemaire, T. Subkowski, C. Bollschweiler, G. Turner, B. Nüsslein and R. Fischer 2006 Use of laccase as a novel, versatile reporter system in filamentous fungi. App. Environ. Microbiol., 72(7): 5020-5026

Mansur, M., T. Suárez and A. E. González 1998 Differential gene expression in the laccase gene family from basidiomycete I-62 (CECT 20197). App. Environ. Microbiol., 64: 771-774

Mayer, A. M. and R. C. Staples 2002 Laccase: new functions for an old enzyme - a review. Phytochem., 60: 551-565

Michniewicz, A., R. Ullrich, S. Ledakowicz and M. Hofrichter 2006 The white-rot fungus Cerrena unicolor strain 137 produces two laccase isoforms with different physico-chemical and catalytic properties. App. Environ. Microbiol., 69(6): 682-688

Michniewicz, A., S. Ledakowicz, T. Jamroz, A. Jarosz-Wilkolazka and A. Leonowicz 2003 Decolorization of aqueous solution of dyes by the laccase complex from Cerrena unicolor. Biotechnologia, 4: 194-204

Morozova, O. V., G. P. Shumakovich, M. A. Gorbacheva, S. V. Shleev and S. V. Yaropolov 2007 "Blue" laccases. Biochemistry (Moscow) 72(10):1136-1150

Nazaruk, E., K. Sadowska, J. F. Biernat, J. Rogalski, G. Ginalska and R. Bilewicz 2010 Enzymatic electrodes nanostructured with functionalized carbon nanotubes for biofuel cell applications. Anal. Bioanal. Chem., 398: 1651-1660

Ng, T. B. 2004 Peptides and proteins from fungi. Peptides, 25: 1055-1073

Okamoto, K., Y. Ito, I. Shigematsu, S. O. Yanagi and H. Yanase 2003 Cloning and characterization of a laccase gene from the white-rot basidiomycete Pleurotus ostreatus. Mycoscience, 44: 11-17 
Padgett, R. A., M. M. Konarska, P. J. Grabowski, S. F. Hardy and P. A. Sharp 1984 Lariat RNAs as intermediates and products in the splicing of messenger RNA precursors. Science, 225: 898903

Palmieri, G., P. Giardina, C. Bianco, B. Fontanella and G. Sannia 2000 Copper induction of laccase isoenzymes in the ligninolytic fungus Pleurotus ostreatus. App. Environ. Microbiol., 66: $920-924$

Pezzella, C., F. Autore, P. Giardina, A. Piscitelli, G. Sannia and V. Faraco 2009 The Pleurotus ostreatus laccase multi-gene family: isolation and heterologous expression of new family members. Curr. Gen., 55: 45-57

Rodríguez-Couto, S. and J. L. Toca-Herrera 2006 Industrial and biotechnological applications of laccases: A review. Biotechnol. Advan., 24: 500-513

Rogalski, J., A. Dawidowicz, E. Jóźwik and A. Leonowicz 1999 Immobilization of laccase from Cerrena unicolor on controlled porosity glass. J. Mol. Catal. B: Enzymatic, 6: 29-39

Rogalski, J., A. Hatakka, B. Longa and M. Wojtas-Wasilewska 1993 Hemicellulolytic enzymes of the ligninolytic white-rot fungus Phlebia radiata-influence of phenolic compounds on the synthesis of hemicellulolytic enzymes. Acta Biotechnol., 13: $53-57$

Rogalski, J. and A. Leonowicz 1992 Phlebia radiata laccase forms induced by veratric acid and xylidine in relation to lignin peroxidase and manganese-dependent peroxidase. Acta Biotechnol., 12: 213-221

Rogalski, J. and G. Janusz 2010 Purification of extracellular laccase from Cerrena unicolor. Prep. Biochem. Biotechnol., 40: $242-255$

Rushmore, T. H., M. R. Morton and C. B. Pickett 1991 The antioxidant responsive element: activation by oxidative stress and identification of the DNA consensus sequence required for functional activity. J. Biol. Chem., 266: 11632-11639

Rushmore, T. H., R. G. King, K. E. Paulson and C. B. Pickett 1990 Regulation of glutathione S-transferase Ya subunit gene expression, identification of a unique xenobiotic-responsive element controlling inducible expression by planar aromatic compounds. Proc. Nat. Acad. Sci. USA, 87: 3826-3830

Sambrook, J., E. F. Fritsch and T. Maniatis 1989 Molecular cloning: a laboratory manual, $2^{\text {nd }}$ ed., Cold Spring Harbor Laboratory Press, New York

Shleev, S., M. Klis, Y. Wang, J. Rogalski, R. Bilewicz and L. Gorton 2007 Comparative spectroelectrochemical studies of lyophilized and nonlyophilized laccases from Cerrena unicolor Basidiomycete. Electroanalysis, 19(10): 1039-1047

Soden, D. M. and A. D. W. Dobson 2001 Differential regulation of laccase gene expression in Pleurotus sajor-caju. Microbiology, 147: $1755-1763$

Soden, D. M. and A. D. W. Dobson 2003 The use of amplified flanking region-PCR in the isolation of laccase promoter sequences from the edible fungus Pleurotus sajor-caju. J. App. Microbiol., 95: 553-562

Sójka-Ledakowicz, J., J. Lichawska-Olczyk, S. Ledakowicz and A. Michniewicz 2007 Bio-scouring of linen fabrics with laccase complex from Cerrena unicolor. Fibres \& Textiles in Eastern Europe 15, No. 4(63): 86-89

Thiele, D. J. 1992 Metal-regulated transcription in eukaryotes. Nucl. Acids Res., 20: 1183-1191

Walker, J. M. 2002 The protein protocols-Handbook. $2^{\text {nd }}$ ed, Humana Press Inc., Totowa

White, T. J., T. Bruns, S. Lee and J. W. Taylor 1990 Amplification and direct sequencing of fungal ribosomal RNA genes for phylogenetics. In "PCR Protocols: A Guide to Methods and Applications" ed. by M.A Innis, D. H. Gelfand, J. J. Sninsky and Whiteededs, Academic Press, Inc., New York. pp. 315-322

Xu, F., W. Shin, S. H. Brown, J. A. Wahleithner, U. M. Sundaram and E. I. Solomon 1996 A study of a series of recombinant fungal laccase and bilirubin oxidase that exhibit significant differences in redoxpotential, substrate specificity, and stability. Bioch. Biophys. Acta, 1292: 303-311 